\title{
Diakonova O.G.•
}

DOI: 10.25108/2304-1730-1749.iolr.2018.55.122-139

\section{Legal status of persons participating in production of psychiatric and psychological expert examinations}

\begin{abstract}
Generally, rights and obligations of persons participating in an appointment and production of forensic expert examination are to some extent specified by law. However, we can see that with all the certainty of legal status of an expert, defender, victim, suspect, accused and their legal representatives, there are significant gaps and controversial points in the law that create obstacles to the exercise of their rights and legitimate interests by these participants of criminal proceedings.
\end{abstract}

Keywords: psychological and psychiatric expert examination; participants of expert examination; decision; petition; legal status.

Forensic expert examinations, an object of which is living people, most seriously affect rights and legitimate interests of citizens. Currently, the problem of legal status of a person in criminal process as a whole is being resolved, the legal status is taking shape, more or less worthy positions of an individual in the rule of law state. However, many problems concerning the guarantees of realization of individual rights are still remained.

Rights of suspect, accused, victim and witness at appointment and production of forensic expert examination are defined in Article 198 Code of Criminal Procedure (hereinafter, the $\mathrm{CCP}$ ). So, at implementing the right to get acquainted with the decision on an appointment of a forensic examination, an investigator has to give necessary explanations about an essence and possibilities of expert

\footnotetext{
- Diakonova Oksana Gennadiyevna - PhD in Law, Orenburg State Agrarian University, Orenburg, Russia. E-mail: mopi_sid@yahoo.com
} 
examination, the meaning of special terms, etc. Right to declare a challenge to an expert or to petition for a forensic examination in another expert institution shall be correlated with the right to request the involvement of experts or persons who have been identified as experts, or to make a forensic examination in a particular expert institution. In connection with the peculiarities of organization of medical institutions at production of forensic psychiatric expert examinations, this right, in fact, can be realized in the case of petitioning for the production of expert examination, for example, not in a psychiatric institution located in a given subject of the Russian Federation, but immediately at the MSCS and FP named after V.P. Serbsky, although this requires a fairly good reason, for example, the presence of one of the reasons for the withdrawal of experts.

Petitions for inclusion of additional questions to the expert in the decision on an appointment of a forensic expert examination should be considered by the person (body), which appoints the forensic examination, especially carefully, since they can be found important issues that fell out of an investigator's (court's) field of vision. Investigators often do not give them due a proper attention. According to the questioning conducted by us with investigators, lawyers' petitions for forensic expert examination in relation to their clients are not satisfied in $77 \%$ of cases, the grounds are most often "improperly formulated questions" and "lack of grounds for appointing an examination in the case materials in accordance with the provisions of Article 196 of the CCP”.

In addition, a suspect, accused, defender provided with right to participate with permission of an investigator at production of forensic expert examination, to give explanation to an expert and familiarize to expert opinion or information on impossibility to give expert report, and also with record of expert's interrogation (cl. 5, 6 of p. 1 of Article 198 of the CCP).

In our view, the norm of p. 2 of Article 198 of the CCP in certain extent infringes the rights of a victim and witness in e part of an appointment and conduct 
of forensic expert examination. More correct is a solution of this question in Article 244 of the Code of Criminal Procedure of the Republic of Kazakhstan [4], where a victim at production of forensic examination is provided with same rights as a suspect and accused person, and namely: 1) before conducting examination to be familiarized with a decision on its appointment and receive clarification concerning his rights, about which a record is drawn up; 2) to declare a challenge of an expert or petition about removal of examination's production of forensic institution; 3) to petition on an appointment as experts indicated by him individuals or employees of concrete forensic institutions, and also on production of examination by commission of experts; 4) to petition on putting before expert additional questions or refinement prior put; 5) with the permission of an investigator to be present at examination, to give explanations to an expert, except the cases that prevent the production of expert examination. If the body, which conducts the criminal proceedings, satisfy a petition a victim, suspect, accused are notified of the place and time of examination. In this case, participation of a body conducting a criminal process is mandatory. Failure to be appeared of an informed person does not prevent the production of expert examination; 6) to be familiarized with expert opinion or information on impossibility to give expert report after it receiving by an investigator, to submit his remarks, file petitions about interrogation of an expert, an appointment of additional or repeated examination, and also conducting new expert examinations. Wherein a witness, in respect of which forensic examination is conducted, has the same rights as above mentioned persons.

Note that the $\mathrm{CCP}$ of Kazakhstan clearly determined the time of familiarization with decision on appointment of forensic examination of a suspect, accused, and victim - before production of examination. This is presented to be right. 
Rights of indicated persons after production of expert examination and familiarization with expert opinion are described in details (cl. 6 of p. 1 of Article 244 of the CCP of Kazakhstan). It seems that these rights might be listed in cl. 6 of p. 1 of Article 198 of the CCP of RF, but indicated rights provided by law a victim, suspect, accused, defender accordingly by cl.5 and 11 of Article 42, cl. 5 of p. 4 of Article 46, cl. 5 and 11 of p. 4 of Article 47, cl. 8 of p. 1 of Article 53 of the CCP of RF.

We believe that a victim could be fully provided with all rights that a suspect, accused and defender at appointing and conducting a forensic examination. In addition, if an expert examination is carried out in respect of a witness, then he must be also provided with the same rights as are available for other persons specified in Article 198 of the CCP. It is necessary, therefore, to enshrine these rights in the law by introducing certain supplements in Article 198 of the CCP.

Right to participate at production of forensic examination in respect of live persons requires a separate consideration. General provisions concerning the production of forensic examination and enshrined in Articles 197, 198, p. 2 of Article 18, cl. 3 of p. 2 of Article 426 of the CCP of RF and Article 24 of the Law "On Expert Activity" indicate on opportunity participation at production of examination a suspect, accused, victim, witness, legal representative and defender, and also person who appointed a forensic examination. It is considered that participants of the process who are present at examination have no right to interfere in researching process, but they may give explanations and ask questions to an expert relating to a subject of forensic examination. However, as far as the production of examination of a live person, there are peculiarities, in this connection; general norms apply only if there is no special rule changing common order. Article 36 of the Law "On Expert Activity" allows participation at production of forensic examination in respect of live persons those participants of process to who such right provided by procedural legislation of Russian 
Federation. Presence of other participants of a process is allowed with permission of a body or person, which appointed a forensic expert examination, and a person in respect of which the forensic examination is conducted or his legal representative. This order shall guarantee rights the both those participants of a process, legal interests of which this examination is touched, and rights and legal interests of a person in respect of which an examination is conducted. Possibility of participation of an investigator at production of expert examination comes off the meaning of Article 197 of the CCP of RF, unlike earlier acting CCP of RSFSR the CCP provides an obligation of an expert to reflect in the expert opinion the fact of presence of an investigator. Investigator may receive from expert clarifications in course of examination and to give his own explanations on issues indicated in the decision. It is supposed that such opportunity is provided other persons, who have, in compliance with acting criminal procedural law, the right to appoint a forensic examination.

In practice, at production of expert examinations, more often a question arises on presence of a defender, legal or other representative of minor in respect of which examination is conducted. Wherein, there is an opinion that their right on presence follows from the requirements of procedural law and therefore there is no required anybody permission. However, the CCP provides a defender (cl. 5 of p. 1 of Article 53), legal representative of minor accused or suspect (cl. 3 of p. 2 of Article 426 of the CCP), and also legal representative of a person, in respect of which an issue on application of compulsory medical measures is decided (cl. 4 of p. 2 of Article 437 of the CCP) the right to participate in 'investigative actions', i.e. in actions on collection and verification of proofs, carrying out by an investigator, inquiry body, prosecutor in established order. The same way is resolved an issue with 'court actions'.

S.N. Shishkov believes [2, p. 170], and it is difficult not to agree to him, actions of experts-psychiatrists and expert-psychologists on conducting of special 
research are related neither 'investigative' nor 'court' one. This action have a specific nature, therefore the right to be presence at production of forensic expert examination in respect of live person, when somebody of participants of process is provided by it, is especially stipulated and is not automatically followed from the right of that or other subject to participate in investigative or court actions. Continuing said, we conclude that for presence at production of forensic examination in respect of live person a defender or other representative of an examinee (except his legal representative) is necessary preliminary permission of a body, which appointed the examination, and also consents of an adolescent examined and his legal representative. According to S.N. Shishkov, in order a legal representative to be participated at production of forensic expert examination in respect of living person it is necessary to get a permission of a body that appointed the examination; consent of the examinee is not required. However it seems that at production of forensic psychological examination (hereinafter, the FPE), complex forensic psychological psychiatric examination (hereinafter, the CFPPE) and forensic psychological expert examinations it is an important component is to create some psychological atmosphere in all interrelations of the expertspsychiatrists and a person-examinee. It should be kept in account by a body (person), which appoints the FPE or other forensic expert examination in respect of live person. In addition, it cannot be forgotten that during production of the FPE (like any other examination in respect of living person) a person, in respect of whom examination is conducted, and an expert may discuss the issues, which are medical secrecy.

There is one moment that arises at production of the FPE in respect of a person who suffers from psychic disorder: presence of some persons is able to harm his psychic health. For instance, presence of accused during expert examination of psychically ill man - a victim of his criminal actions will be able to 
cause of an aggravation of painful process and significantly worsen mental state of a patient [1, p. 171].

Thus, before making a decision on presence or refusing it, a body appointing an expert examination is obliged to find out an opinion of person in respect of whom the examination is appointed and his legal representative (if there is no question concerning presence the legal representative himself). Decision made and its mandatory substantiation should be contained in a decision (determination) about appointment of a forensic examination. If decision about participation of person at production of the FPE or CFPPE is made after its appointed, then it, as Shishkov justly believes, must be reflected in separate decision (determination). Refusal of a person sent for examination and his legal representative to give consent for participation should be written, but unlike a subject, which appoints the examination, they are not obliged to motivate their disagreement.

An issue on presence of a victim, witness, suspect, accused at production of forensic expert examination, in our opinion, must be solved uniquely - if indicated persons are not a subject of examination, they should not be present during the examination.

It is an interest a suggestion of E.V. Mischenko that an insane (since it is quite often such person is appeared in criminal proceedings on the basis of report of the FPE or the CFPPE) must have his procedural status, completely deferent from other persons. He can be neither a suspect nor accused nor defendant. The author offers to call an insane - "a person, in respect of which is solved a matter on application of coercive medical measures" and gives a list of rights of this participant of criminal process. He indicates that legal status is formed only from rights and legal interests as this subject cannot perform duties though it may be available an elementary obligation, for instance, to be present in court proceedings, if his mental condition does not impede in it [3, p. 139]. In addition, such person cannot in person fully exercise his rights; his legal must help him in that $[3, \mathrm{p}$. 
105]. Indeed, presence of rights presupposes an existence of certain duties. In our opinion, a legal representative of an insane, who help him in realization of rights and legal interests, has to help also in performing his obligations.

It should also focus on rights of suspect, accused, defender, victim and witness after receiving an expert opinion by an investigator. In compliance with provisions of part 1 of Article 206 of the CCP, investigator is obliged to present an expert opinion or inform on impossibility to give the opinion. Law indicates that suspect, accused and defender have right to petition on appointment of additional or repeated expert examination. Concerning a victim and witness part 2 of Article 206 of the CCP indicates that an expert opinion is produced to them, wherein say nothing about informing them concerning impossibility to give the opinion and are determined their rights.

So an issue of the rights of indicated persons has been resolved in Article 254 of the CCP of the Republic of Kazakhstan: after familiarization with expert opinion a suspect, accused, victim, witness, who subjected to examination, have right to give their explanations and submit objections of conclusions of an expert examination.

It seems justified a concrete determination of a list of the rights of indicated persons in Article of the CCP. It should especially note the right to give objections.

Indicated explanations should be introduced in a record of familiarization of a victim, suspect, accused, defender and witness, if an expert examination is conducted in respect him/her, in this connection indicated information could help an investigator and court in conducting of assessment of an expert opinion.

\section{References}

1. Kommentaryi k Ugolovno-protsessual'nomu kodeksu Rossyiskoyi Federatsii [Commentary to the Code of Criminal Procedure of Russian Federation]/ pod red. I.L. Petrukhin [Ed. by I.L. Petrukhin]. Moscow, 2003, 896 p. 
2. Kommentaryi k Federal'nomu zakonu "O gosudarstvennoyi sudebnoekspertnoyi deyatel'nosti v RF" [Commentary to the Law "On State Forensic Expert Activity in RF"]. Moscow, 2002,

3. Mischenko E.V. Protsessual'no-pravovoe regulirovanie prinudel'nykh mer meditsinskogo kharaktera [Procedural legal regulation of coercive medical measures]. Dis... kand. yurid. nauk [PhD in Law Diss.]. Orenburg, 1999, 190 p.

4. Ugolovno-protsessual'nyi kodeks Respubliki Kazakhstan [Code of Criminal Procedure of Kazakhstan Republic]. Available at: http://www.base.spinform.ru/ show _ doc.fwx?regnom $=1272$ 